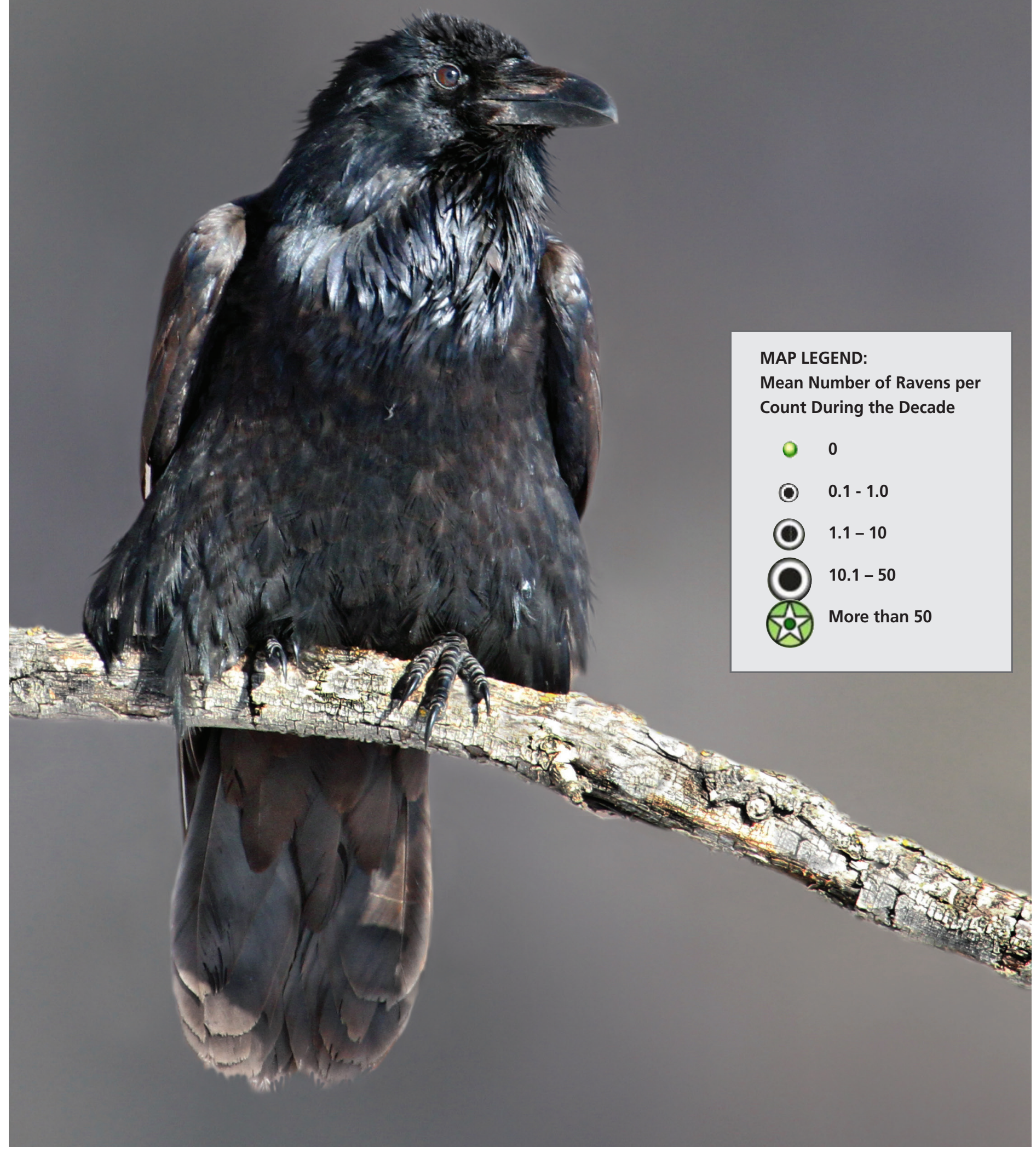




\section{THE COMMON RAVEN REOCCUPIES SOUTHERN SASKATCHEWAN}

Dale G. Hjertaas

15 Olson Place

Regina, SK S4S 2J6

\section{Estelle Hjertaas}

322 12th Ave.

Prince Albert, SK S6V 1C1

The Common Raven (Corvus corax), and hereafter 'Raven', was once a common resident of the prairie and parkland regions of Saskatchewan as well as of the boreal forest, present across the prairies and extending down into the Dakotas". " With the advent of settlement, the Raven disappeared from the prairie and

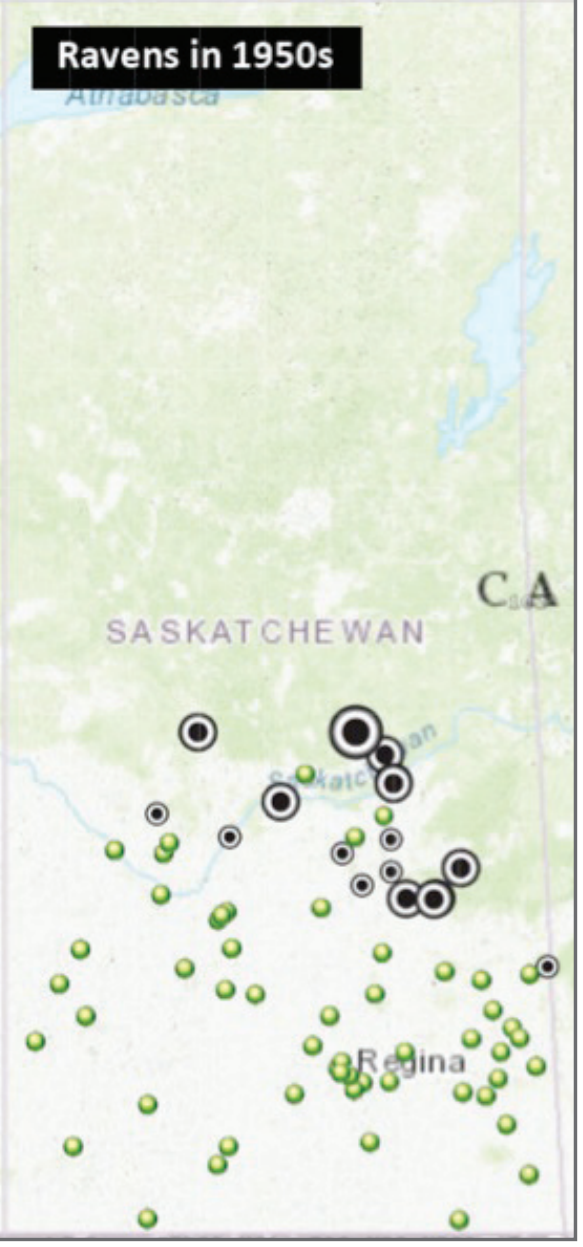

FIGURE 1. Distribution and Abundance of Common Ravens on CBCs from 1950 to 1959. parkland regions, and was apparently absent from areas south of the boreal by 1910 . Houston ${ }^{1}$ notes that the last summer report was in 1893 at Rush Lake, that John Gunn saw them in winter at Good Spirit Lake until around 1908 and that Lawrence Potter saw three between 1901 and 1915 at Eastend and then no more.

Recently the Raven has reoccupied much of its former range. We were intrigued both by the expansion of the Raven population into the Aspen Parkland and Mixed Prairie, but also by the question of why, after an absence of so many years, did the population recolonize much of its

\section{Ravens in 1960s}

Athabasca

()

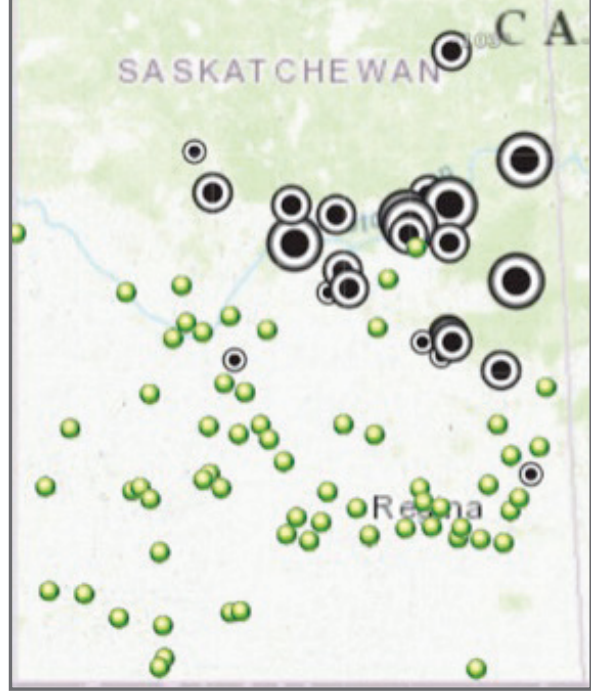

FIGURE 2. Distribution and Abundance of Common Ravens on CBCs from 1960 to 1969. former range. We used Christmas Bird Count (CBC) data to examine the nature of the range expansion.

There were few CBCs prior to 1950, so we examined distribution of Ravens beginning in the 1950s. The mean number of Ravens per count was calculated for each count area for each decade and then plotted (Figures 1-7). Our prime focus was presence or absence of Ravens, so we treated observations from the count period the same as count day observations. Occasionally there were two or more counts conducted by different observers for the same location and same year. In these cases, the highest count for that year was used. Also, occasionally counts

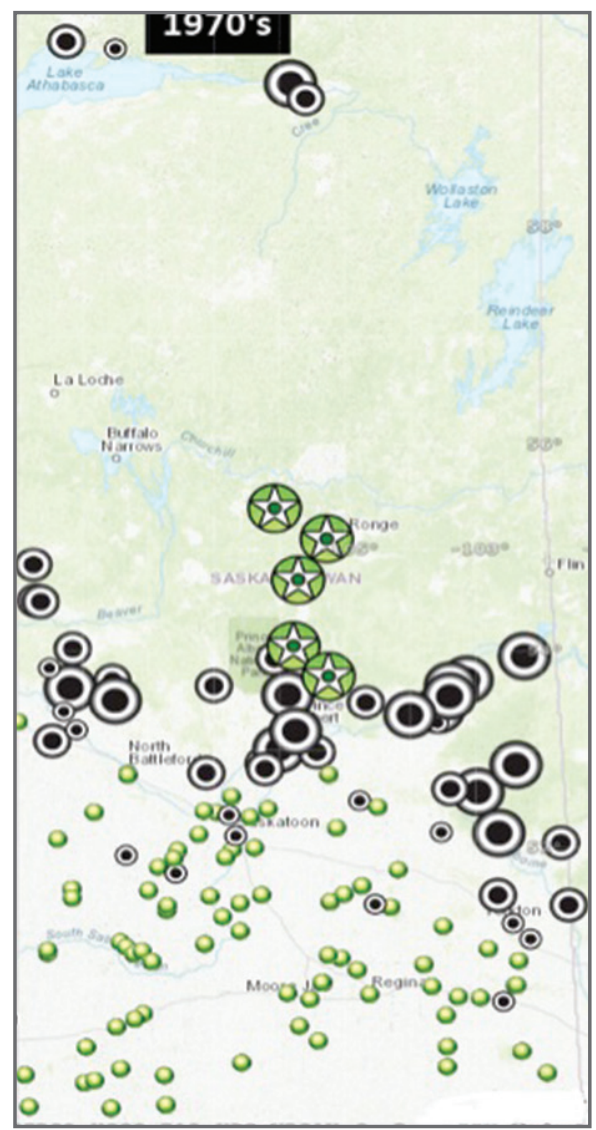

FIGURE 3. Distribution and Abundance of Common Ravens on CBCs from 1970 to 1979 
with different names, such as Big Muddy and Big Muddy Lake appear to have surveyed the same area as was counted in a previous year under the different name. These locations were treated as one and plotted under the first name used.

Vegetation Zones refer to the Natural Vegetation Zones of Saskatchewan as presented in Birds of Saskatchewan. ${ }^{2}$

In the 1950s Ravens were primarily observed only on CBCs in the Southern Boreal Forest and the northern edge of the Aspen Parkland (Figure 1). No CBCs were conducted in the Northern Boreal Forest or Subartctic Woodland during that decade. The most southerly counts with Ravens were at Naicam and Rose Valley in the Aspen Parkland and High Hill and Madge Lake at the south edge of the Southern

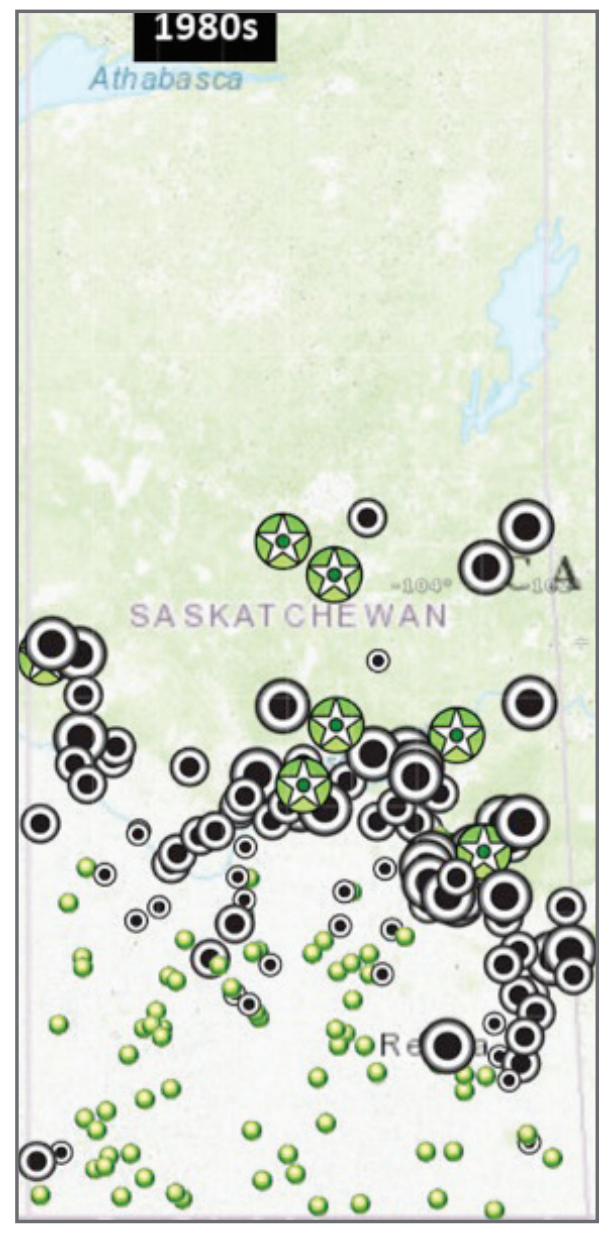

FIGURE 4. Distribution and Abundance of Common Ravens on CBCs from 1980 to 1989.
Boreal Forest. The number of Ravens recorded was small. The highest counts were 14 at Prince Albert (1958), 10 at the Somme (1951) and 13 at Nipawin-White Gull Creek (1954). A grand total of 152 Ravens were counted during the decade.

During the 1960s, Ravens were primarily observed on counts in the Southern and Northern Boreal Forest. Single Ravens were observed twice in Saskatoon and two were observed at Saltcoats in 1967. However, sightings in the Parkland remained rare (Figure 2). The number observed rose modestly with Prince Albert, Hudson Bay, Nipawin, Nipawin Squaw Rapids, Nipawin - White Fox, and Cumberland House having mean counts of more than 10. A total of 360 Ravens were counted during the decade with high counts of 40 at Prince Albert (1968) and 49 at

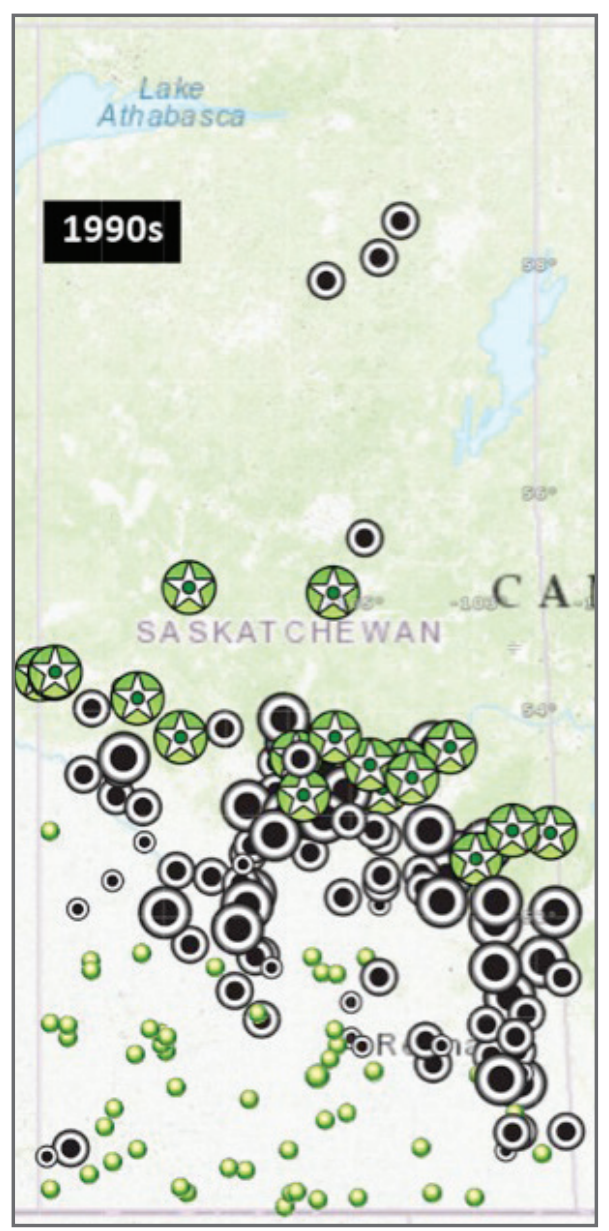

FIGURE 5. Distribution and Abundance of Common Ravens on CBCs from 1990 to 1999.
Nipawin (1966).

The total number of Ravens observed during the 1970s increased to 2,069 , an increase of 57 per cent from the 1960s. This was partly due to larger counts in the forest, with five count areas averaging more than 50 Ravens per count and 18 averaging between 10 and 50 . The first count of more than 100 Ravens was 195 at Besnard Lake in 1974. In 1978, 115 Ravens were recorded at Emma Lake and in 1979, Squaw Rapids became the third CBC to exceed 100 with 148. A definite move south was also apparent. Ravens were observed as far south as Broadview, at a number of other locations in the Aspen Parkland and at Harris and Duperow - Ruthilda in the Mixed Prairie (Figure 3).

In the 1980s, Ravens became well established across the Aspen Parkland (Figure 4) with observations

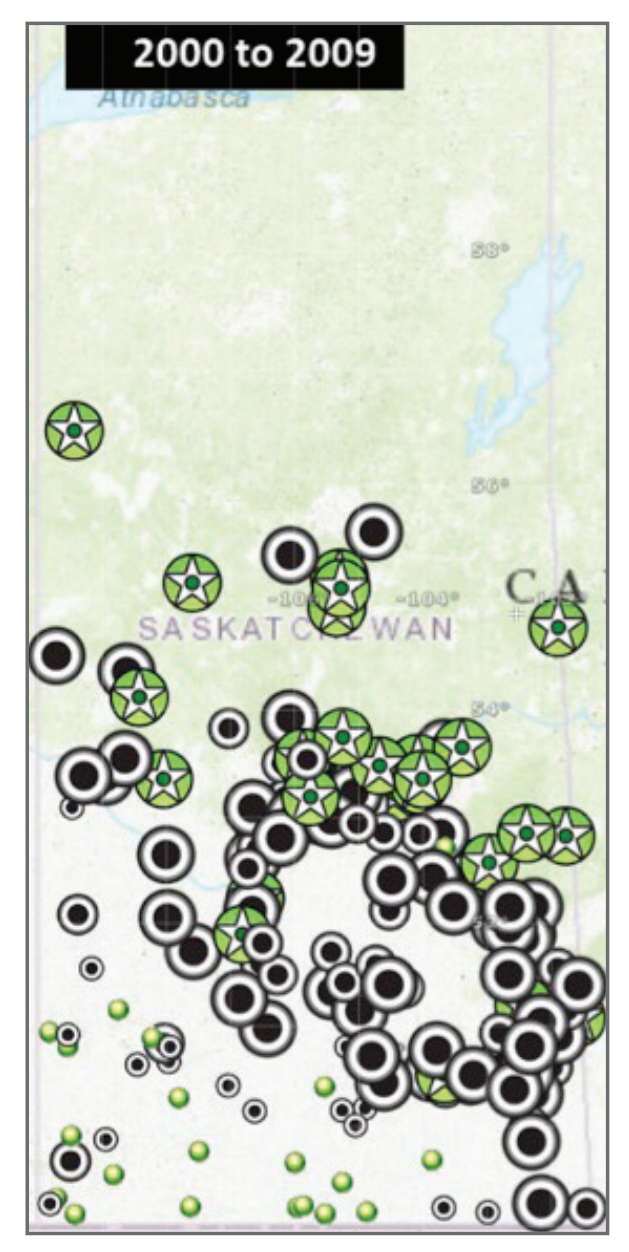

FIGURE 6. Distribution and Abundance of Common Ravens on CBCs from 2000 to 2009. 
as far south as White Bear Lake and at Round Lake, Crooked Lake and Fort Qu'Appelle in the Qu'Appelle Valley. Ravens were observed on several counts in the northern part of the Mixed Prairie including Battleford, Gardiner Dam, Kenaston and Scott, and were observed at both Cypress Hills PP (Centre Block) and Fort Walsh (West Block). The number of ravens on many counts increased compared to the 1970s. The high counts during the decade were 116, 137, 199 and 205 at Grand Centre, La Ronge, Squaw Rapids and Prince Albert respectively. A total of 6,259 Ravens were observed during the decade.

The number of Common Ravens observed on many counts continued to increase during the 1990s.

Eighteen counts had an average of more than 50 Ravens (Figure 5). The

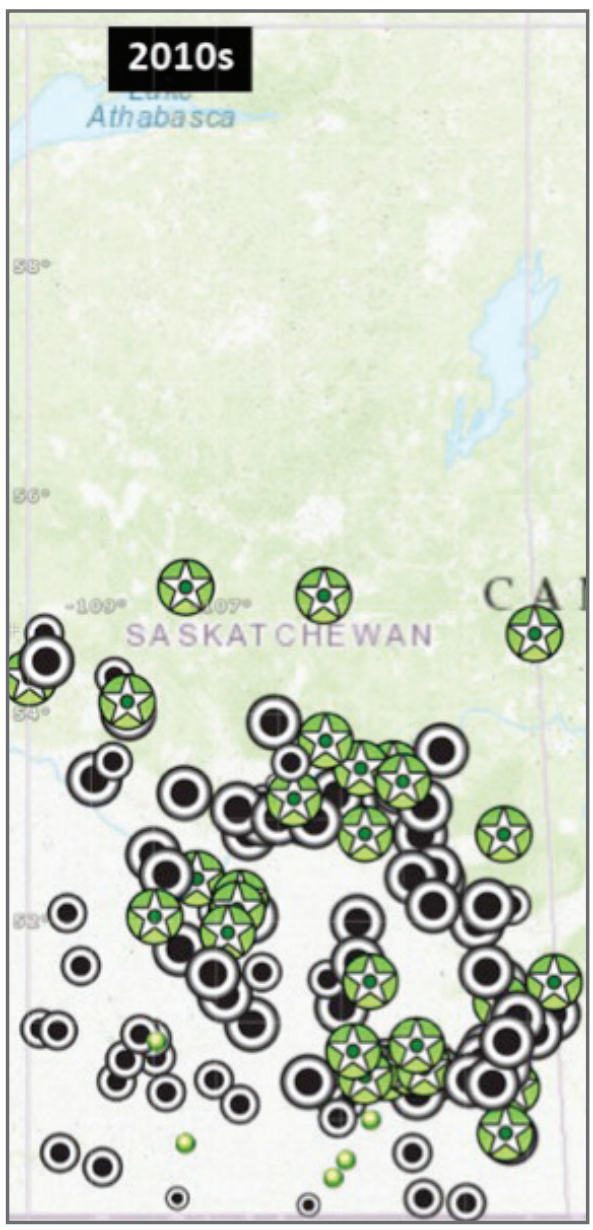

FIGURE 7. Distribution and Abundance of Common Ravens on CBCs from 2010 to 2016. high counts for the decade were at Hudson Bay (393), Emma Lake (309) and Prince Albert (307). Each of these single counts was more than double the total number of Ravens counted across the province during the 1950s. The expansion southward continued as Ravens appeared at a number of new locations including Arcola, Craven, Indian Head, and Luseland. Nearly 17,000 Ravens were recorded during the decade.

In the 2000s, the movement of Ravens south into the Mixed Prairie and the Dry Mixed Prairie was striking (Figure 6). Ravens were first observed on a Regina CBC in 2000. They occurred in the southeast at Gainsborough, Oxbow, Estevan and Bromhead. In central Saskatchewan they were found as far south as Avonlea and Briercrest and in the west were observed on counts at Shamrock, Saskatchewan Landing Provincial Park, Cabri, Leader North, Morse and Govenloch. The only area where no Ravens were found was the area north of the US border between Weyburn and Eastend.

During the first six years of the 2010s, the species essentially completed their reoccupation of their former range in Saskatchewan. Ravens were observed as far south as Grasslands National Park and Coronach. While birders on a few counts did not find any Ravens, there are no regions where the Raven is absent. The high counts so far during the decade have been 508 at Nipawin and 509 at Hudson Bay.

Aside from the maps, a second way to evaluate the expansion is simply by numbers (Figure 8 ). The number of Ravens observed increased gradually in the 1950s and 60 s and then at a more rapid rate from the 70 s to 90 s with the increase at least temporarily stopping after reaching a peak of 5,501 in 2012.

The number of CBCs conducted annually has increased from around 20 in the 1950s to between 80 and 100 since 1990. The mean number of Ravens observed per active count, i.e. number of Ravens divided by number of counts conducted that year, has increased from zero in 1942 to more than 60 in 2012 (Figure 9). Clearly the range expansion and the higher individual counts were the main factor in the large increases, not just the increase in number of counts.

CBCs have been conducted regularly, although not every year, at Prince Albert and Nipawin in the Southern Boreal Forest and La Ronge in the Northern Boreal Forest, with counts at Nipawin going back to the 1940s, Prince Albert to the 1950s and La Ronge counts since 1971. Though there is significant year to year variation, the general pattern is clear. Extremely low numbers in the 40s with a high count of two at Nipawin, very low counts in the 1950 s with only one count over 10 , a modest increase in the 60s and 70 s and then accelerating growth through 2010 (Figure 10). The pattern is consistent with the broader pattern observed by looking at forest sites on the maps, so it is reasonable to accept this as the pattern on Raven population change in the forest.

Why has the Common Raven reoccupied the range it had abandoned nearly a century earlier? Their disappearance was probably driven by death from poison and traps set for predators ${ }^{3}$ and by a lack of food after disappearance of the bison and other large mammals on whose carcasses the Ravens depended for winter food. ${ }^{1}$ A key condition for their recolonization of southern Saskatchewan is undoubtedly that food is again available across the prairie and parkland. Large mammals have returned in the form of livestock and deer. Occasional carcasses provide a 


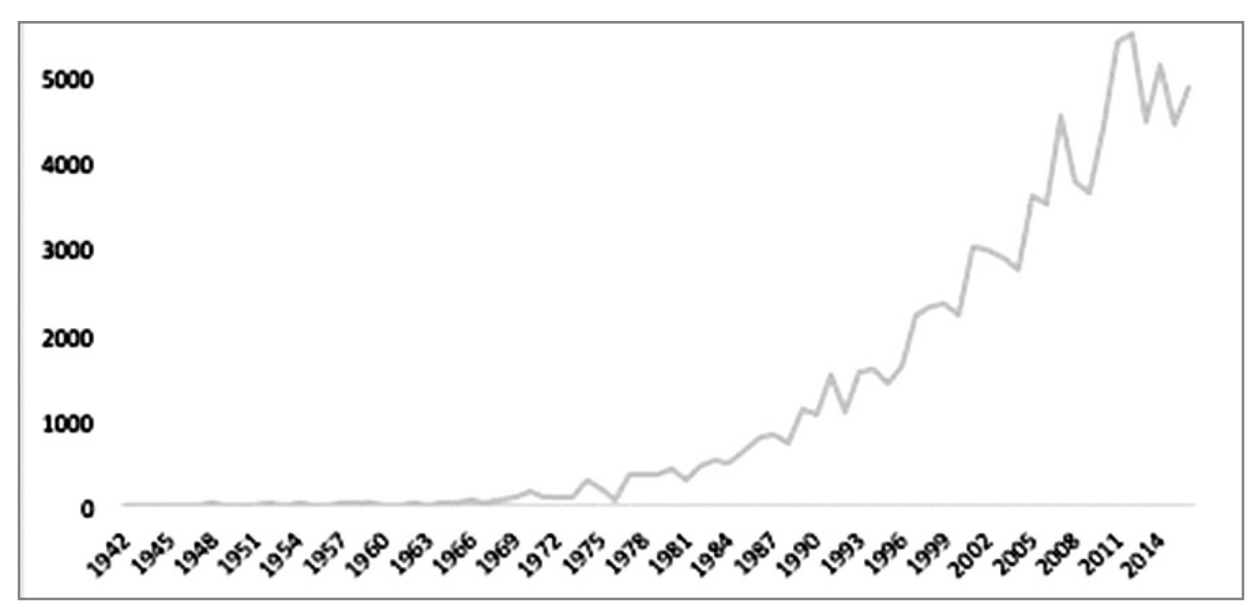

FIGURE 8. Total number of Common Ravens observed on Saskatchewan Christmas Bird Counts from 1942 to 2016.

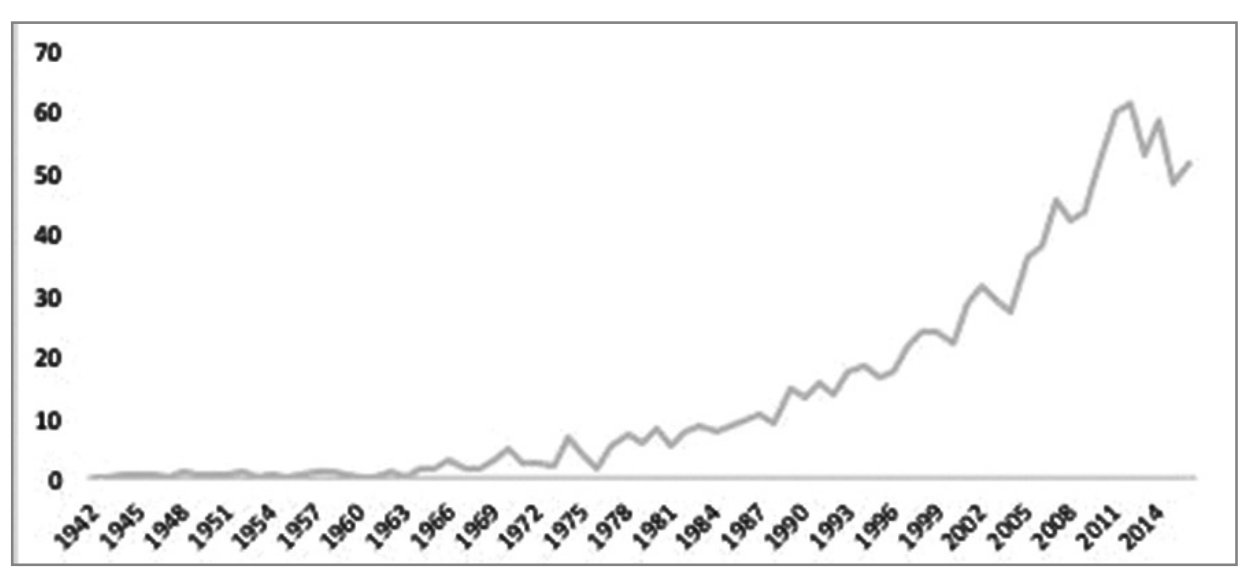

FIGURE 9. Mean number of Common Ravens per active count observed on Saskatchewan Christmas Bird Counts from 1942 to 2016.

food resource that was not present after the bison had been eliminated and before farming introduced new potential food sources. Landfills and road kill of large and small wildlife provide additional food sources.

Historically, Ravens on the prairie and parkland would have moved to follow bison herds and other food sources. Today they probably aggregate in winter in good feeding areas, such as landfills. This is a probable explanation for the difference between counts from Yorkton and Good Spirit Lake (Figure 11). Although these two count areas are only $35 \mathrm{~km}$ apart, the Good Spirit Lake count is centered on a provincial park and includes significant areas of aspen forest and wetland while the Yorkton count is centered on the city and includes more farmland and the municipal landfill. Ravens were first in 1972 and have been observed on each $C B C$ since then, with numbers slowly increasing but only exceeding 50 on one occasion, in 2002 when 93 were counted (Figure 11). At Yorkton, Ravens arrived later and only became common in 1989. Numbers increased steadily after that with a high count of 411 in 2013. The key point is that in both areas, numbers remained low for a period and then increased with the much higher numbers reached at Yorkton probably reflecting the greater availability of winter food at the Yorkton Landfill and other urban

While food is a critical factor and will be a key determinant of ultimate winter populations, there have clearly been suitable food sources in southern Saskatchewan for decades, so an appropriate question might be observed on the Good Spirit Lake CBC sources. why Ravens took so long to reoccupy their former range.

Reinvasion requires a population source. Ravens clearly expanded south from the boreal forest. For a significant population expansion to occur the Boreal Forest population had to generate surplus birds which could emigrate. Assuming the growth pattern shown at Prince Albert, Nipawin and La Ronge (Figure 10) represents the pattern for the Boreal Forest in general, the boreal population was not producing surplus birds in the 1950s. As the population in the forest grew over succeeding decades, there were more individuals to pioneer new areas and as a greater percentage of potential territories in the forest were occupied, pressure on younger birds to seek new breeding areas likely increased. Later, as populations grew in colonized areas such as Yorkton, these areas became sources for further colonists. However, we argue that a growing Raven population in Northern Saskatchewan was critical for the recolonization of the south.

Ravens were never eliminated in northern Saskatchewan as this area did not see the catastrophic loss of almost all large mammals which occurred in the Aspen Parkland and Mixed Prairie. Why was the Raven population low in the north? Stewart ${ }^{3}$ suggested that poison contributed to the demise of Ravens, and that Ravens would have continued to be vulnerable. Spears ${ }^{4}$ commenting on the return of Ravens to the Ottawa area, also blamed strychnine for their previous low populations. Hayes described arriving at a strychnine bait site in the Yukon and finding a grizzly bear, two wolves, 10 Ravens, six Magpies and many chickadees dead. ${ }^{5}$ Poisoning with strychnine baits was not confined to southern Saskatchewan. Baits were spread in many parts of the forest for wolf 


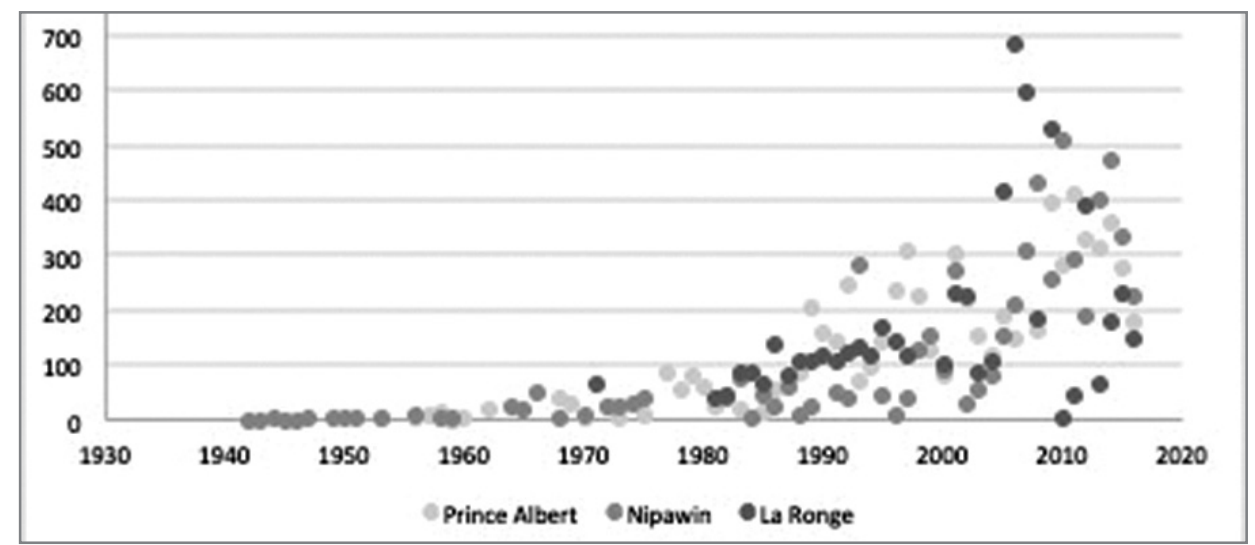

FIGURE 10. Number of Ravens Observed on CBCs at La Ronge, Prince Albert and Nipawin 1942-2016.

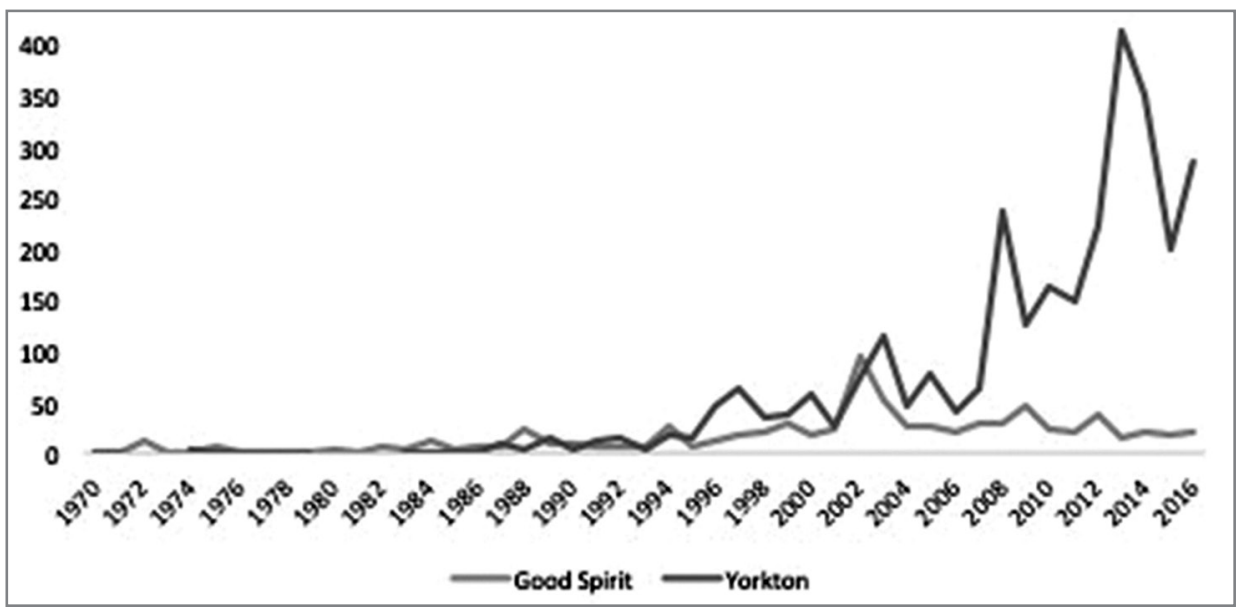

FIGURE 11. Ravens Observed at Good Spirit Lake and Yorkton CBCs.

control. The use of strychnine officially came to an end in Saskatchewan in 1967, but it is likely that poisoning continued for several years in some locations as northern offices used up their stocks of strychnine. Tim Trottier, Fish and Wildlife Branch, Sask Environment, reports that at least some poisoning was occurring in 1975, but believes most use of strychnine ended by the early 1970 s (Personal communication Tim Trottier, December 11, 2006). A decline in poison use in the 1960s and cessation of setting strychnine baits in the 1970s offers a possible explanation for the modest increase in Raven population observed in the late 1960s and the much greater population increase in the 1970s and thereafter. When mortality from poisoning was reduced, the Raven population began to grow. A larger population then expanded into southern areas.

\section{Conclusion}

The Common Raven, once a bird of the Boreal Forest, Aspen Parkland and Mixed Prairie, disappeared from its prairie and parkland ranges during shows a slow recolonization of the parkland and then the grassland ecoregion beginning in the latter 1960 s and accelerating in the 1990s and 2000s. By 2016, Ravens occurred throughout the province with only a small number of CBC counts in any year not reporting Ravens. The most important factor in this reoccupation was probably that the prairie and parkland are again suitable habitats for the Raven with winter food sources such as landfills, road killed animals, dead livestock and big game killed by coyotes, hunters or other factors. In addition, cessation of poisoning predators, especially wolves in the boreal forest, probably the 1800s. Our analysis of CBC data reduced mortality of the Raven population in the forest, allowing the Boreal Forest population to grow and produce the colonists that expanded into more southern areas.

\section{Acknowledgements}

This project began when Estelle Hjertaas, then a high school student, extracted all Raven counts from the Christmas Bird Counts in our extensive Blue Jay collection. A first draft of the paper was prepared from that data and submitted to the Blue Jay. The editor, Anna Leighton, recommended we redo the paper to include all CBCs where no Ravens were seen. While we agreed that would improve the paper it meant substantial work and other activities interfered, so the project spent a decade on hold. When Dale Hjertaas retired, he reactivated the project. We thank Al Smith for providing the spreadsheet containing all Christmas Bird Count data, Glen McMaster for assistance with graphing, Anna Leighton for her recommendations to improve the analysis, Dave MacDonald for help in learning ArcGIS to create the maps, and Dr. Mark Brigham for his thoughtful review.

1. Houston, C.C. 1977. Changing Patterns of Corvidae on the Prairies. Blue Jay 35:149-56

2. Smith, AR, Houston CS, Roy JF. 2019. Birds of Saskatchewan. Manley Callin Series No. 8, Special Publication No. 38. Nature Saskatchewan, Regina, Sask.

3. Stewart, Robert E. 1975. Breeding Birds of North Dakota. Tri-College Centre for Environmental Studies, Fargo. North Dakota.

4. Spears, Tom. 2009. Return of the Raven. The Ottawa Citizen, August 3, 2009 edition.

5. Hayes, Bob. 2010. Wolves of the Yukon. Wolves of the Yukon Publishing. Cited in Holland, Eva 2018 They're Out There. Canadian Geographic March/April; 34-44. 